\title{
Gölgede Kalmış Bir Şairin Bilinmeyen Üç Tercümesi
}

\author{
İsmail GÜLEÇ* \\ Güler DOĞAN AVERBEK**
}

$\ddot{\mathbf{O} z}$

Son yıllara kadar hakkında neredeyse hiçbir bilgi bulunmayan Emirî mahlaslı Mehmed bin Musa Paşa hem anne hem baba tarafından pek çok âlim, sanatkâr ve devlet adamı yetiştiren bir aileye mensuptur. 16. asırda Anadolu'da Farsça şiir söyleme geleneğini sürdüren Emirî, bugün elde olan bütün eserlerinde Farsça ve Türkçeyi bir arada kullanmıştır. Yakın geçmişte sadece iki divanı ile bu divanlarda sözünü ettiği eserlerinden haberdar olunan Emirî’nin, Uppsala Üniversitesi Kütüphanesi’nde bulunan yazma bir külliyatta üç tercüme eserine daha rastlanmıştır. Yazmadaki sırasına göre bu metinler, Sadî’nin Bostân, Hâcûyı Kirmânî’nin Kemâlnâme ve Hilâlî-i Çağatayî’nin Slfâtü'l-Âşskîn adlı eserlerinin Farsçadan Türkçeye manzum tercümesidir. Emirî, Kemâlnâme yerine tercümesinde Ahlâk-ı Kâmilîn adını kullanmış, diğer iki eseri ise aynı isimle tercüme etmiştir. Bu çalışmada Emirî’nin hayatına dair yeni bulgulara kısaca temas edildikten sonra söz konusu yazma ile adları zikredilen üç tercüme metin tanıtılacak ve yazmadan örnek sayfalar verilecektir.

Anahtar Kelimeler: Emirî, 16. asır Türk edebiyatı, Fars edebiyatı, tercüme geleneği, Bostân, Kemâlnâme, Slfâtü' 'l-Âşlkîn

\footnotetext{
* Prof. Dr., İstanbul Medeniyet Üniversitesi, Edebiyat Fakültesi. Türkiye. Elmek:ismail.gulec@medeniyet.edu.tr

**Dr. Öğr. Üyesi, İstanbul Medeniyet Üniversitesi, Eğitim Bilimleri Fakültesi. Türkiye.

Elmek: guler.dogan@medeniyet.edu.tr
} 
Three Unknown Translations By An Undervalued Poet

\begin{abstract}
Until recently, there was almost no information available about Mehmed bin Musa Pasha, who wrote with the nom de plume (makhlas) Emirî. He was born into a family with many scholars, poets and statesmen on both his paternal and maternal sides. In the 16th century, Emirî followed the tradition of Persian poetry in Anatolia and used Persian and Turkish languages together in his works. Although we, up until recently, only knew two of his divans and his other works he cited in these works, three of his translations have been discovered in a compendium of manuscripts found in the Library of Uppsala University. Following the order given in the said compendium, these three translations in verse from Persian to Turkish are Bustan of Sa'di, Kamalnama of Khwadju-yi Kirmani and Sifat al-Ashiqin of Hilali-i Chaghatayi. While keeping the original titles of the two works, Emirî changed the title of Kamalnama into Akhlaq al-Kamilin in his Turkish rendering. Following some brief information on the new findings about Emirî's life and works, this study introduces the said manuscript and three translations in question, with certain excerpts from the manuscript.
\end{abstract}

Keywords: Emirî, $16^{\text {th }}$-century Turkish classical literature, Persian literature, tradition of translation, Bustan, Kamalnama, Sifat al-Ashiqin. 


\section{Giriş}

Uppsala Üniversitesi Kütüphanesi'nde yer alan yazma bir eserde Emirî mahlasını kullanan bir şair tarafından kaleme alınmış Bostân, Kemâlnâme'nin Ahlâk-ı Kâmilîn adıla yapılmış tercümesi ve yine Slfâtü 'l-Âşıkin tercümesine tesadüf ettik. Yazmadaki metinlerin incelenmesi sonucu bu tercümelerin, 16. asırda Farsça-Türkçe şiirler yazan ve Emirî mahlasını kullanan Mehmed bin Musa Paşa adlı bir Anadolu şairine ait olduğu görülmüştür.

Emirî hakkında biyografi kitaplarında şu ana kadar herhangi bir malumata rastlanamamıştır. ${ }^{1}$ Aynı araştırmacı tarafından Emirî’nin ikinci divanında yer alan Farsça şiirler üzerine yapılan üç akademik çalışma dışında bir başka çalışmaya da tesadüf edilmemiştir. ${ }^{2}$ Söz konusu çalışmaların ilkinde, Emirî’nin Sultan III. Murad'a (saltanatı: 1574-95) sunduğu ikinci ve dördüncü divanından hayatı ve eserleriyle ilgili bilgiler derlenmiş ve bazı değerlendirmeler yapılmıştır. ${ }^{3}$ Neredeyse kaleme aldığı her eserinde hayatına dair bazı bilgiler verdiği görülen şair hakkında bu yazıda tanitılacak tercümeler sayesinde daha çok şey biliyoruz.

Emirî, Sadrazam Pirî Mehmed Paşa'nın (ö. 1532) damadı Candaroğlu Musa Paşa'nın (ö. 1544?) oğludur. ${ }^{4}$ Ahlâk-ı Kâmilîn tercümesinde söylediğine göre "evliyalar şehri" Boluludur. ${ }^{5}$ Bostân tercümesinde asil bir aileden geldiğini bildirmektedir. ${ }^{6}$

Dördüncü divanın Millî Kütüphane'de bulunan yazma nüshasında yer alan ve "Du'â be-Rûh-1 Ecdâd Rahmetullâhi Aleyhim Ecma 'în” başlığını taşıyan

\footnotetext{
1 Emirî hakkında Dr. İsa Akpınar tarafından detaylı bir çalışma hazırlanmakta olduğundan burada hayatı hakkında tafsilatlı malumat verilmeyecektir.

2 Söz konusu çalışmalar şunlardır: Yasemin Yaylalı, "Emîrî Divanı," Doktora Tezi, Atatürk Üniversitesi, Sosyal Bilimler Enstitüsü, 2013; "Emîrî'nin İkinci Divânındaki Farsça Şiirlerinde Geçen Ayetler," ILTED 2/46 (2016): 247-267; "Emîrî Divan'ında Geçen Şahsiyetler,” Atatürk Üniversitesi Türkiyat Araştırmaları Enstitüsü Dergisi 63 (2018): 117-134. Tezde Emirî'nin eldeki iki eseri olan ikinci ve dördüncü divanları tanıtılmış ve ikinci divanda yer alan Farsça metinler inceleme ve Türkçe tercümeleriyle birlikte yer almıştır. Araştırmacının ifadesine göre ikinci divanın tek, dördüncü divanın ise biri Süleymaniye Yazma Eser Kütüphanesi'nde biri Millî Kütüphane'de olmak üzere iki nüshası tesbit edilebilmiştir. İkinci divanda bulunan ve söz konusu tezde yer verilmeyen ve ayrıca dördüncü divanda yer alan Emirî’nin Türkçe şiirleri, tarafımızca neşredilmek üzere çalışılmaktadır.

3 Yaylal, agt, s. 19-32.

4 Yaylalı, agt, s. 19.

5 Emirî, Ahlâk-ı Kâmilîn, yazma eser, Uppsala Üniversitesi Kütüphanesi, nr. O Vet. 63, $181^{\text {b }}$.

6 Emirî, Bostân, yazma eser, Uppsala Üniversitesi Kütüphanesi, nr. O Vet. 63, 168 .
} 
şecerede Emirî tek tek dedelerini sayar.7 Söz konusu şecereye göre Emirî’nin babası ve dedeleri sırasıyla şöyledir: Mehmed (Emirî)-Musa-Sürh Ahmed- İbrahimEmir İsfendiyar ${ }^{8}$-Bayezid Han ibn Âdil-Âdil-Mîr Yakub-Şemseddin-Alp Arslan-Nureddin. Neticede bu soy yukarıda Halid bin Velid'e (ö. 642) kadar ulaşır. ${ }^{9}$ Emirî şecerede ayrıca Mir Yakub'un, Kırım Hanı'nın damadı olduğunu söyler. Zikredilen isimlere bakıldığında içlerinde birçok emir ve komutanın olduğu görülür. Halid b. Velid ile başlayan ve devam eden, aralarında Emir lakabıyla meşhur olanların da bulunduğu asker bir ailenin çocuğu olarak Emirî’nin, mahlasını seçerken ailesinin bu durumunu göz önüne aldığını söyleyebiliriz. Ayrıca daha sonra bahsedileceği üzere kendisinin emirlik görevinde bulunmuş olması da bu mahlasi tercih etmesinde etken olmalıdır.

Emirî’nin doğum tarihini tahmin etmeye yarayacak en kıymetli işaretlerden biri ikinci divanında yer alan şu beyitte geçer:

Ömrem ki resîde be-ser-i evvel-i heştâd

Hâzır ne-şodem hayf Emîrî ki dî-mûyem ${ }^{10}$

Her ne kadar hazırlanan doktora tezinde bu beyitteki can alıcı ifade "(bin beş yüz) seksenler” olarak tercüme ediliyorsa da burada bir itiraz hakkı doğmaktadır. ${ }^{11}$ Evvela belirtmek gerekir ki Emirî’nin yaşadığ 1 asırda miladi tarihlerin kullanıldığı çok nadirdir. Bu beyitte geçen "heştâd" kelimesi şayet tarihe atıf ise en iyi ihtimalle “(dokuz yüz) seksenler” demek lazımdır ki 980/1570’ler divanın tertip edildiği tarih olan 996/1587-88'den uzak bir tarihtir. Burada zannımızca şair, yaşından bahsetmektedir ve artık 80'li yaşlara ulaştığını söylerken zımnen ölümün yaklaştı̆ıını ifade etmekte ve hazırlık yapmadığ Şayet 996/1587-88'de 80 yaşında olduğunu düşünürsek Emirî, 916/1510-11'de dünyaya gelmiş olmalıdır. Bu yazıda tanıtacağımız yazmadaki tercümelerin en geç tarihlisi ise 1001/1592-93 yılında tamamlanmıştır. Dolayısıyla Emirî'nin, hicrî hesaba göre en az 85 yıl yaşadığını söylemek mümkündür. Nitekim Emirî, 996/1587-88 ile 1001/1592-93 yılları arasında yazıldığını kesin olarak bildiğimiz

\footnotetext{
7 Emirî, Dîvân, yazma eser, Millî Kütüphane, nr. Yz A 85, $76^{\text {b. }}$.

$8 \mathrm{Bu}$ yazıda tanıtılacak tercüme metinlerden ilki olan Bostân için yazılan ilk takrizde de Emirî'nin İsfendiyar oğullarından olduğu dile getirilmektedir.

9 Yukarıda bahsi geçen doktora tezinde bu şecereye epeyce yer ayrılmış ve burada sıralanan ve çoğu Candaroğulları emirleri olan isimler hakkında tafsilatlı malumat verilmiştir (Bk. Yaylalı, agt, s. 21-32).

10 Emirî, Dîvân-ı Sânî, yazma eser, Süleymaniye Yazma Eser Kütüphanesi, Fatih Koleksiyonu, nr. 3780, $120^{\text {b }}$.

11 İlgili değerlendirme için Bk. Yaylalı, agt, s. 19-20.
} 
eserlerinde zaman zaman ihtiyarlığından dem vurmaktadır. ${ }^{12}$

Emirî, Ahlâk-ı Kâmilîn'in "yazılmasına yakın bir zamanda" yani 1000/1591-92 yılına yaklaşırken Derviş ve Nur Ahmed adında iki oğlunun şehit olduğunu söylemektedir. ${ }^{13}$ Oğullarına koyduğu isimler, bize Emirî’nin manevi temayülleri ve meşrebi hakkında fikir vermektedir. Bu isimlere bakarak onun ehl-i tasavvuf olduğunu, en azından tasavvufa uzak olmadığını söyleyebiliriz.

Aslen Bolulu olan şair, divanlarını Sultan III. Murad'a sunduğu dönemde İstanbul'da olmalıdır. Nitekim yeri geldiğinde değinileceği gibi, divanlarına takriz yazan isimlerin o dönemde İstanbul'da olmaları da buna işaret etmektedir. Sifâtü'l-Âşıkin'in sebeb-i nazm kısmında dile getirdiğine göre bu eseri tercüme etmeden, yani 1000/1591-92'den önce hacca gitmiştir.

Emirî’nin hemen her eserinde dile getirdiği en önemli hususlardan biri emirlik vazifesinde bulunmuş olmasıdır. Bostân tercümesi için Emir Mehmed tarafından yazılan takrizden, Emirî'nin, emirlik görevini, merkezi Bursa olan Hüdavendigâr sancağında ifa ettiğini öğreniyoruz. ${ }^{14}$ İstinsahı 997/1589'da tamamlanan dördüncü divanın sonuna bizzat yazdığı ve "Bende-i kemter Emirî Mehmed bin Musa Paşa el-ma 'zûl an livâ"' şeklinde imzaladığı başlıksız manzumeye göre sancak beyliğinden azledileli 10 yıl olmuştur. ${ }^{15}$ Dolayısıyla Emirî’nin en geç 987/1579-80 y1lında veya daha öncesinde emirlik görevinden azledildiğini düşünmek mümkündür.

Sancaktaki görevinden ayrılmış olmasını pek çok kez ifade eden Emirî, zaman zaman bu vazifesinden azledilmiş/ayrılmak zorunda kalmış olmanın verdiği üzgünlük ve kırgınlığı dile getirirken bazen de her şeyden elini eteğini çekmesinin kendisi için sancak beyliğinden daha iyi olduğunu söyler. ${ }^{16}$ Emirî, bazen de sancaktan ayrılmış olmasına rağmen nazmının güzelliğinin, içinde bulunduğu duruma delil olduğunu ve artık söz âleminin emiri olduğunu söyleyerek bir anlamda kendini teselli eder. ${ }^{17}$ Emirî’nin, görevinden kendi isteğiyle değil, kendisini çekemeyenlerin

12 Emirî, Dîvân-l Sânî, 82 $2^{\mathrm{b}}, 115^{\mathrm{b}}$; Emirî, Slfâtü 'l-Âşskkin, yazma eser, Uppsala Üniversitesi Kütüphanesi, nr. O Vet. 63, 240 ; Emîrî, Dîvân-ı Râbi ', yazma eser, Süleymaniye Yazma Eser Kütüphanesi, Fatih Koleksiyonu, nr. 3780, $228^{\text {b }}$. 13 Emirî, Ahlâk-l Kâmilîn, 181'.

14 Emirî, Bostân, $173^{\mathrm{a}}$.

15 Emirî, Dîvân-l Râbi', fevaid.

16 Emirî, Dîvân-ı Sânî, 85a .

17 Emirî, Ahlâk-ı Kâmilîn, 197b. 
belki iftirasıyla veya haksız olduğunu düşündüğü bir nedenden dolayı ayrıldığını, içinde bulunduğu ruh halini dile getirdiği beyitlerden anlamak mümkündür. ${ }^{18}$

Daha sonra değinileceği üzere üç ayrı eserine yazılan takrizleri kaleme alan kişiler, Emirî'nin çevresini göstermesi açısından önemlidir. Takrizlerden anlaşıldığına göre Emirî İstanbul'da bulunduğu zaman zarfında ilmiye sınıfina yakındır, Bolu'da bulunduğu esnada ise daha ziyade ehl-i tasavvuf kimselere yakındır. İstanbul'da iken takriz yazan hemen herkesin müderris olması, Emirî'nin de sancak beyliğinden azledildikten sonra müderrislik yapmış olma ihtimalini akla getirmektedir. Nitekim eserlerinden, müderrislik için yeterli donanıma sahip olduğu anlaşılmaktadır. Ayrıca dönemin önemli isimlerinin takriz yazmaları Emir̂̂’nin, devrinde bilinen ve önemli bir isim olduğunu göstermektedir.

\section{Eserleri}

Dördüncü divanın sonuna yazdığı ve yukarıda bahsi geçen manzumede dört divan ile Işknâme ve İâdetnâme adlı eserleri kaleme aldığını söyleyen Emirî, Ahlâk-ı Kâmilîn'in sebeb-i nazm bölümünde de Ahlâk-ı Kâmilîn'den önce Râznâme isimli bir eseri tamamladığını dile getirmektedir. ${ }^{19} \mathrm{Bu}$ durumda Emirî’nin bilinen eserleri ikinci divan, dördüncü divan, Bostân Tercümesi, Slfâtü'l-Âşıkîn Tercümesi, Ahlâk-ı Kâmilîn adlı Kemâlnâme tercümesi; ele geçmeyen eserleri ise birinci divan, üçüncü divan, Işknâme, İrâdetnâme ve Râznâme' dir. $^{20}$

Ayrıca Emirî’nin, ikinci divanın baş tarafına dercettiği müstakil iki tercüme daha vardır. Bunlar Şems-i Tebrizî’nin (ö. 1247?) aynı adlı eserinden tercüme ettiğini söylediği Mergûbü' 'l-Kulûb ${ }^{21}$ ile Mevlânâ'nın (ö. 1273) aynı adlı eserinden tercüme ettiğini dile getirdiği Heft Vâdî’ dir. ${ }^{22}$

İkinci divanın sonuna düşülen nottan bu divanın Emirî’nin elyazısıyla

18 Emirî, Dîvân-ı Sânî, 124

19 Emirî, Ahlâk-ı Kâmilîn, 181 .

20 İstanbul Üniversitesi Nadir Eserler Kütüphanesi’nde Farsça Yazmalar 1222 numarada kayıtlı Farsça bir divanı burada anmakta fayda vardır. Emirî mahlasını kullanan bir şair tarafından Kanuni Sultan Süleyman'a sunulan divanın, bu çalışmada bahsedilen ve Kanuni'nin saltanatı süresince berhayat olduğu artık bilinen Emirî olup olmadığı ayrıca ele alınıp değerlendirilmelidir (Divanın metin tespiti ve incelemesi için bk. Serpil Koç Konuksever, "Emîrî Divanı: Metin İnceleme,"Yüksek Lisans Tezi, İstanbul Üniversitesi, Sosyal Bilimler Enstitüsü, 2012).

21 Her ne kadar bu eserin Şems-i Tebrizî’ye ait olup olmadığı hususunda araştırmacılar hemfikir değilse de sözkonusu eseri Şems'e nisbet eden pek çok yazma nüshası ve baskısı mevcuttur.

22 Her iki metin de İsa Akpınar tarafından neşredilmek üzere çalışılmaktadır. Bu iki eserin nâzımlarıyla ilgili tartışmalara da söz konusu çalışmada temas edileceği düşünülmektedir. 
vücuda getirildiği anlaşılmaktadır. ${ }^{23}$ Aynı ciltte yer alan dördüncü divan Fethullah ibnü'ş-Şemseddin el-Abbâsî tarafından istinsah edilmiştir. Bu divanın Millî Kütüphane nüshası ise Emir̂̀’nin elyazısıyla vücuda getirilmiştir. Burada şu hususa dikkati çekmekte fayda vardır: Ferağ kayıtlarına göre dördüncü divanın her iki nüshası da 997 senesi Ramazan ayında (14 Temmuz-12 Ağustos 1589) tamamlanmıştır.

İkinci divanın başında Seyyid Mehmed es-Su'ûdîn (ö. 1591) ve Süleymaniye Medreseleri müderrislerinden Feyzullah tarafından yazılmış iki takriz yer almaktadır. ${ }^{25}$ Emirî’nin kendi yazdığı dördüncü divan nüshasının en baş1na dercettiği manzum mensur tek sayfalık bir metin, yine divanın baş tarafında Mehmed Emîn es-Sâbıkî tarafından kaleme alınmış uzunca bir takriz ve aynı sayfada müderris İsa tarafından düşülmüş dört satırlık not şeklinde bir takriz yer almaktadır. Divanın sonunda ise imzasından anladığımıza göre takrizi yazdığı dönemde Semaniye Medreseleri'nde müderris olan ve daha sonra Hakaniye-i Vefa Medresesi müderrisliğine tayin edilen Kâtipzade Zeynî ${ }^{26}$ (ö. 1603) ile İstanbul'da müderrislik yapan İbrahim'in takrizleri yer almaktadır.

\section{Emirî’nin şiiri ve şairliği}

Eldeki bütün eserlerini sancak beyliğinden azledildikten sonra kaleme alan Emirî, makta1 Farsça yazılmış bir gazelinde, sancaktaki görevinden ayrılalı hayli zaman olduğunu haber verirken söz ülkesinde kendisine rengîn bir sancak bahşedildiğini ifade eder. ${ }^{27}$ Buradan şunu anlamak da mümkündür: Mehmed bin Musa Paşa sancaktaki görevi sona erdikten sonra şiir yazmaya başlamış ya da en azından eser telif etmeye ve tercümeye ağırlık vermiş olmalıdır. Bugün elde olan bütün eserleri bu iddiayı teyit eder niteliktedir. Ayrıca "Emîrî gerçi pîr oldı dahi eş’âra düşsem dir”28 diyerek özellikle yaşl1lık döneminde mesaisini şiire hasretti-

23 Emirî, Dî̀ân-ı Sânî, 181 a

24 Ebussuud Efendi’nin mülazımı olan, şiir yazdığı bilinen ve aynı zamanda Târîh-i Hind-i Garbî’nin müellifi olan Mehmed Su'ûdî, coğrafya âlimidir. Takrizi yazdığı dönemde Süleymaniye Medreseleri'nde müderris olması muhtemeldir (Ayrıntılı bilgi için Bk. Cevat İzgi, "Mehmed Suûdî Efendi," Türkiye Diyanet Vakfi İslâm Ansiklopedisi, c. 28, Ankara: Türkiye Diyanet Vakfi, 2003, s. 526-527).

25 Emirî, Dî̀ân-ı Sânî, fevaid.

26 Ayrıntılı bilgi için Bk. Mehdin Çiftçi, "Hankâh-Vefâ İlişkisi Bağlamında İstanbul'daki Üç Medrese: Ka'riye, Hâkâniye-i Vefâ ve Vefâ Medreseleri," Uludağ Üniversitesi İlahiyat Fakültesi Dergisi 25/1 (2016): 1-49.

27 Emirî, Dîvân-ı Râbi ', 223 ${ }^{\text {b }}$.

28 Emirî, Dîvân-ı Sânî, 85 . 
ğini ifade eden Emirî, bir başka yerde ise "Gâh geh pîrâne ser cûş eyledükçe nazm ile" ${ }^{29}$ ifadesiyle yaşlılık döneminde şiire merak sardığını dile getirmektedir.

Yaşı itibariyle Emirî, özellikle tercüme etmek üzere metin seçerken lirizmin hâkim olduğu şiirlerden ziyade didaktik metinleri tercih etmiş olmalıdır. Âşıkane ve rindane şiirleri söyleyecek yaşı geçtiğinden olsa gerek tercümeleri ve bu metinlere yaptığı eklemeler hikemi ve irfanidir. Divanında yer verdiği Türkçe gazellerin çoğu ise dikkat çekici bir şekilde âşıkanedir. Yaşı itibariyle Emirî’nin bu şiirleri hissederek söylemekten ziyade bilgisiyle söylediğini düşünmek veya bu tarz gazellerini daha erken yaşlarda yazdığını düşünmek mümkün olabilir.

Edebî açıdan değerlendirildiğinde Emirî’nin şiirlerinin vasatın altında olmadığı görülecektir. O, kendisini Rum'un bülbülü olarak tanımlar. ${ }^{30}$ Müderris Feyzullah'a göre ise zamanın ikinci Câmî'sidir. ${ }^{31}$ Eldeki eserlerinin hepsinin müellif nüshalarının bulunmasından anlaşıldığı kadarıyla bu eserler, takrizlerdeki sitayişkâr ifadelere rağmen, istinsah edilme imkânı bulamamıştır. ${ }^{32}$ Burada dikkat çekici olan husus Emirî’nin de şiirlerinin edebiyat muhitlerinde yayılmadığını bilmesi ve bunu divanında dile getirmesidir. ${ }^{33}$

\section{Uppsala Yazması}

$\mathrm{Bu}$ yazı aracılığıyla ilim camiasına ve ilgililere tanıtılmak istenen yazma, Uppsala Üniversitesi Kütüphanesi’nde O Vet. 63 numarada kayıtlıdır ve bir külliyattır. Yaptığımız araştırmalar neticesinde bu yazma ve muhtevası hakkındaki ilk malumatın, Uppsala Üniversitesi Kütüphanesi’ndeki Arapça, Farsça ve Türkçe yazma eserler için Carl Johan Tornberg tarafindan Latince olarak hazırlanan ve 1849'da neşredilen Codices Arabici, Persici et Turcici Bibliothecae Regiae Universitatis Upsaliensis adlı katalogda yer aldığını gördük. ${ }^{34}$ Bu katalogdaki bilgilerden anlaşıldığ kadarıyla Tornberg, yazmadan çıkarılabilecekler haricinde

\footnotetext{
29 Emirî, Dîvân-ı Sânî, 124

30 Emirî, Bostân, $170^{\text {a }}$.

31 Emirî, Dîvân-l Sânî, fevaid.

32 Saraya sunduğu yazmadaki dördüncü divanın müstensih hattı olması anlaşı1ır bir durumdur.

33 Emirî, Dîvân-l Sânî, 84 ; ayrıca bk. Emirî, Dîvân-ı Râbi ‘,212 ${ }^{\mathrm{b}}$.

34 Carl Johan Tornberg, Codices Arabici, Persici et Turcici Bibliothecae Regiae Universitatis Upsaliensis, Uppsala, 1849, s. 98-99. Daha sonra Ali Muhaddis, Uppsala Üniversitesi Kütüphanesi'nde bulunan Farsça yazmalar üzerine çalışmış ve kütüphanenin internet arama sayfasındaki bilgiye göre bu yazmadan da söz etmiştir. Maalesef bu çalışmaya ulaşma imkânımız olmadı (Çalışmanın künyesi: Ali Muhaddis, Concise Catalogue of the Persian Manuscripts in Uppsala University Library, Uppsala: Uppsala University, 2013).
} 
malumata sahip değildir.

Söz konusu yazmanın fiziki özellikleri şu şekildedir: Yazmanın tamamı 290 varaktır. Üç ayrı eserin yer aldığı yazmada her eser sonrasında boş sayfalar bırakılmıştır. Manzum metinlerin olduğu sayfalar çift sütuna 17 satır şeklindedir. Yazmanın dış ölçüleri 203 x 145 x 44 mm'dir. Sözbaşları kırmızıdır. Bütün metinler reddadelidir. Sadece üçüncü sırada yer alan metnin ilk iki sayfasına cetvel çekilmiş ve cetvelde varak kullanılmıştır. Yazmanın miklepli ve şemseli olan cildi, siyah deridendir. Yazmaya varak numarası verilmeden önce bir yerde varak kaybı olmuştur.

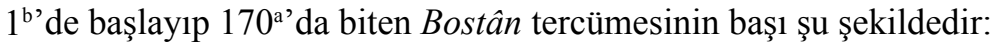

Hudâvend-i 'arş $u$ zemîn-i zamân

Anun zîr-i hükmindedür ins ü cân

Farsça kaleme alınan sonu ise şöyledir:

Çün konem rıhlet ezîn dâr-l fenâ

Cem 'i ihvân-râ be-mâned yek-nişân

$176^{\text {b' }}$ de manzum-mensur karışık bir mukaddimeyle başlayan ve $229^{\text {a }}$ da sona eren Ahlâk-ı Kâmilîn adlı tercümenin mensur ifadelerle başı şu şekildedir:

Bismi'llâhi'r-rahmâni'r-rahîm

El-hamdü li'llâhi'llezi ce 'ale muhabbetühü misbâhu'l-ervâh. Ve nevvera misbâhu'l-ervâh. Ke-dav'u's-sabâh.

$177^{\text {b' }}$ de başlayan manzum kısmın başı şu şekildedir:

Kavl-i men lâ ilâhe illâ hû

Ni 'metiyle cihân içi memlûu

Farsça kaleme alınan sonu ise şu şekildedir:

Ber keşîdem çü na 'ra-i yâ hô

Şod nidâ lâ ilâhe illâ hû

Yazmadaki son tercüme olan ve $235^{\mathrm{b}}$ ile $290^{\mathrm{b}}$ arasında yer alan Sıfâtü'lÂşıkîn şu şekilde başlar:

Hudâvendâ der-i gaybı küşâd it

Cemâlün keşf idüp kalbümi şâd it

Sonu ise şu şekildedir: 
Ümîd oldur olına sehvi ıslâh

Emîrî böyle tahrîk itdi hâme

Her üç metin de eserleri kaleme alan Emirî mahlaslı Mehmed bin Musa Paşa hattıyla yazılmıştır. Emirî, yazma nüshanın başında $1^{\mathrm{a}}$ 'da yer alan Bostân için yazdığı Farsça iki beyti "li-muharririhi el-fakîr Emîrî" şeklinde imzalamıştır. Yazmanın en sonunda $290^{\text {b' }}$ de de bu sefer "li-muharriri ve nâzımihi” notunu düştüğü Slfâtü' $l$ Aş̧ıkin için yazdığı iki Farsça beyit yer almaktadır. Ancak aynı şahıs tarafından yazılmış olmalarına rağmen Bostân tercümesi ve Ahlâk-ı Kâmilîn yer yer divani yazıdan izler taşıyan nesih hat ile Slfâtü' 'l-Aş̧ıkîn tercümesi ise talik hat ile yazılmıştır. Her iki yazı türünde de Emirî’nin oldukça mahir olduğu anlaşılmaktadır.

Ahlâk-ı Kâmilîn ve Sıfâtü'l-Âşıkîn tercümesi 1000/1591-92 senesinde, Bostân tercümesi ise 1001/1592-93 senesinde tamamlanmıştır. Ancak anlaşıldığ kadarıla bu eserleri cilde yerleştirirken mütercim-şair Emirî, Bostân tercümesini en başa almış, üçüncü sırada yer alan eserden daha kısa olan Ahlâk-ı Kâmilîn'i ikinci sıraya ve Slfâtü'l-A̧şskîn'i ise en sona almıştır. Emirî'nin bu sıralamayı, eserlere verdiği ehemmiyete göre yapmış olması muhtemeldir. Eserlerde, tercümelerin tamamlanma tarihi dışında herhangi bir ketebe kaydı yer almamaktadır. Ancak her üç eserin de mütercim nüshası olması ve yazımlarının iki sene içerisinde bitmiş olması, eserlerin istinsahlarının da yakın bir tarihte gerçekleştirilmiş olması ihtimalini kuvvetlendirmektedir.

Yazma, şairi tarafından kontrol edilmiş ve gerekli görülen yerlerde düzeltme ve eklemeler yapılmış, lekelenen veya yazarken deforme olan harfler, okunmasının güç olabileceği mülahazasıyla hemen altlarında tekrar gösterilmiştir. Her üç eser de Emirî'nin bilinen tüm eserlerinde olduğu gibi Türkçe ve Farsça karışık şekilde nazmedilmiştir. Ayrıca her üç metinde de neredeyse her başlı̆ıın sonunda yer alan çoğunlukla iki beyit Farsça kaleme alınmıştır.

\section{Bostân tercümesi}

Sadî-i Şirazî’nin (ö. 1291) Bostân adlı mesnevisinin Emirî tarafından yapılan bu manzum tercümesi, 5460 beyitten oluşmaktadır. ${ }^{35}$ Bunların yaklaşık 1250'si Farsçadır. Tercüme, Şehnâme vezni diye de bilinen ve eserin aslının da vezni olan fe 'ûlün fe 'ûlün fe '̂̀lün fe 'ûl vezniyle kaleme alınmıştır. Bu metnin yer 
aldığg bölümde eksik varak olmadığı değerlendirilmektedir. Emirî, Bostân'ı tercüme ederken takip ettiği yöntemi ve nelere dikkat ettiğini $167^{\mathrm{b}}$ ' de anlatmaktadır. Sadî için tercümenin sonunda "Sühan Der-Medh-i Şeyh Sa“dî ve Du'â-i Ân” başlıklı bir bölüme yer verilmiştir. ${ }^{36}$ Bostân tercümesinin tamamlanmasına düşülen tarih beyti şu şekildedir: ${ }^{37}$

Zi-hâtif ânçünîn üftâd târîh

Çe pend âyed belî în Bostâneş= 1001 [1592-93]

Emirî, Bostân'ın yazılış tarihini ayrıca lafzen de zikretmiştir: ${ }^{38}$

Hezâr u yek idi bu sâl-i hicret

Çekerdüm ben fenâ fikriyle zucret

Bostân tercümesinin sonunda, Mehmed bin Musa Paşa’yı tanıanlar tarafından eser için kaleme alınmış beş takriz ile şairin, kendi tercümesi hakkında yazdığı manzum metin yer almaktadır. Takrizlerden ilki Arapçadır ve Bolu livasından Abdurrahman tarafından kaleme alınmıştır. ${ }^{39}$ İkinci takriz de Arapçadır ve Yıldırım Han Camii Vaizi, Hacı Bayram fukarasından Şeyhzade diye meşhur Mehmed tarafından yazılmıştır. ${ }^{40}$ Daha önce ifade edildiği gibi Emir Mehmed imzasını taşıyan ve Farsça kaleme alınan üçüncü takrizde, Emirî’nin, Hüdavendigâr sancağının beyi olduğu söylenmektedir. ${ }^{41}$ Dördüncü sırada yer alan metin manzumdur ve şairin kendisi tarafından kaleme alınmıştır. ${ }^{42}$ Seyyid Mehmed ibn Seyyid İbadullah ibn Bâlî'nin takrizi Şevval 1001'de (1-29 Temmuz 1593 ) yazılmıştır ve Farsçadır. ${ }^{43}$ Bostân tercümesi için yazılan metinlerin altıncısı da Farsçadır ve Halvetî Şeyhi Abdülgaffar ibnü’ş-Şeyh Muslihiddin (Bolulu) tarafından kaleme alınmıştır. Metne göre Şeyh Muslihiddin'in hoca silsilesi eşŞeyh Hayreddin (ö. 1535), Çelebi Halife (ö. 1494) ve Yahya Halveti eş-Şirvanî (ö. 1464) olarak devam etmektedir. Bu takrizlerden Emirî'nin Bostân'1 Bolu’da yazdığını ve o dönem Bolu'sunun önde gelen âlimlerini tanıdığını anlıyoruz.

36 Emirî, Bostân, $169^{\mathrm{b}}-170^{\mathrm{a}}$.

37 age, $169^{\mathrm{b}}$.

38 age, $170^{\mathrm{a}}$.

39 age, $171^{\mathrm{b}}-172^{\mathrm{a}}$.

40 age, $172^{\mathrm{b}}$.

41 age, $173^{\mathrm{a}}$.

42 age, $173^{\mathrm{b}}$.

43 age, $174^{\mathrm{a}}$. 


\section{Ahlâk-ı Kâmilîn}

İkinci sırada yer alan eser ise Hâcû-yı Kirmânî’nin (ö. 1352) Kemâlnâme adlı eserinin Emirî tarafından Ahlâk-ı Kâmilîn adıyla yapılan tercümesidir. ${ }^{44}$ Ahlâk-ı Kâmilin' in Türkçeye yapılmış başka bir tercümesi henüz tesbit edilmemiştir. 12 bölümden oluşan Ahlâk-ı Kâmilîn'de 56 varakta 1675 beyit yer almaktadır. Yazmanın varak numaraları konmadan evvel, 222. varaktan önce bir varak kopmuştur. Emirî, sebeb-i nazm bölümünde gönül mahzeninde gizli anlamlar olduğu için Râznâme'yi tamamladıktan sonra kalem de elindeyken gönlünün rahat etmediğini ve kış aylarında bu kitabı yazmaya başladığını söylemektedir. ${ }^{45}$ Eserde yer alan ve toplamı 115 beyit olan 22 gazelin tamamı Farsçadır. Ayrıca 683 beyit de Farsçadır. Yani 1675 beyitten oluşan eserin yaklaşı 800 beyti Farsçadır ki bu da eserin neredeyse yarısına tekabül etmektedir. Tercümenin vezni aynı zamanda Kemâlnâme'de de kullanılan vezin olan fe 'ilâtün mefâ iilün fe 'ilün'dür. Metnin aslında olmayan ve Emirî tarafından tercümeye eklenen gazellerde ise muhtelif vezinler kullanılmıştır. Eserin sonlarında Hâcû-yı Kirmânî için "Der-Medh-i Şeyh" başlı̆̆ıyla 11 beyitten müteşekkil bir medhiye kaleme alınmıştır. ${ }^{46}$

Ahlâk-ı Kâmilîn'in sonunda boş olarak bırakılan sayfalardan Emîrî’nin, bu tercümesi için de takrizler yazılmasını arzu ettiği düşünülebilir, ancak sayfaların boş kalmasından bu arzusunun gerçekleşmediği anlaşılmaktadır. Sadece Bostân'da olduğu gibi tercüme metin hakkında kendisi tarafından Farsça olarak kaleme alınmış çoğunluğu manzum, iki sayfalık bir metin yer almaktadır. ${ }^{47}$ Metnin sonunda Bostân tercümesinin başında ve Sifâtü'l-Âşılkîn'in sonunda yer alan Farsça beyitler gibi "li-nâzımihi”" notuyla Farsça iki beyit kaleme alınmıştır. ${ }^{48} 228^{a}$ 'da yer alan tarih kıtasında tercümenin tamamlanmasına şu şekilde tarih düşmüştür:

Çenîn âmed be-dil ilhâm-ı târîh

Safâ-yı cân ki bûd ahlâk-ı nîĝ $=1000$ [1591-92]

\section{Sıfâtü'l- Âşıkîn tercümesi}

Üçüncü sırada yer alan eser ise özellikle 16. asrın ilk yarısında şöhret bulan ve Çağtay Türkü olduğu için Çağatayî nisbesini kullanan Hilâlî’nin (ö. 1529-30)

\footnotetext{
$44 \mathrm{Bu}$ eser, Taner Gök tarafından yayına hazırlanmaktadır.

45 Emirî, Ahlâk-ı Kâmilîn, 181 ${ }^{\mathrm{a}}$.

46 age, $225^{\text {a. }}$.

47 age, $230^{\mathrm{b}}-231^{\mathrm{a}}$

48 age, $229^{\text {b }}$.
} 
kaleme aldığı Sıfâtü' 'l- Âşıkîn ${ }^{49}$ adlı mesnevinin aynı adla yapılmış manzum tercümesidir. Diğer iki metinde olduğu gibi bu metinde de Emirî, eserin aslında kullanılan vezni tercih etmiştir ki o da mefâ îlün mefâ 'îlün fe 'ûlün' dür. Metnin aslında olmayan ve Emirî tarafindan tercümeye eklenen gazellerde ise muhtelif vezinler kullanılmıştır. 264 'ten ve 271 'den sonra yer alması gereken birer varak, şu an yanlış yerdedir. Bu durumun, ilgili forma düzenlenirken karşılıklı iki varağın yanlış aralığa yerleştirilmesinden kaynaklandığı anlaşılmıştır. Metin, toplam 1799 beyitten müteşekkildir. Bu beyitlerin 415'i Farsçadır. 20 bölümden oluşan tercümede her bölümün sonuna metnin aslında olmayan bir gazel eklenmiştir. Bu gazellerin üçü Türkçe kaleme alınmıştır. Bilindiği kadarıyla bu eserin de Emirî’den önce veya sonra Türkçeye yapılmış bir tercümesi yoktur. 290 a' da başlayan kıtada tercümenin tamamlanmasına düşülen tarih şudur::

\section{Be-dil vârid şode ez-gayb târîh}

Rüsûm ez-âşılkân men yâd dâdîm = 1000 [1591-92]

Slfâtü 'l-Âşskîn'in tamamlanma tarihini Emirî, Bostân'da olduğu gibi ayr1ca lafzen de ifade etmiştir: ${ }^{51}$

Zi-hicret çün hezâr âmed me-râ sâl

Be-itmâm âmede în nüsha-i kâl

\section{İmlâ özellikleri}

Genel itibariyle imlâ hususunda özenli olduğu gözlenen Emirî’nin, yazmanın tamamında karşımıza çıkan bir tercihinden söz etmek gerekir. Her ne kadar bu konuda tutarlı olduğunu söylemek mümkün değilse de Emirî, pek çok yerde Türkçe kelimelerde vezin icabı yaptı̆̆ı imaleleri, med harfleriyle göstermeye gayret etmiştir. Mesela kalbümi kelimesinde ikinci hecenin uzun olduğunu göstermek için $b \hat{a}$ harfinden sonra $v \hat{a} v$ harfini eklemiş, eyledi kelimesinde ise ikinci hecenin uzun okunması gerektiğini göstermek için lâm harfinden sonra elif harfini eklemiştir.

İmlâ konusunda dikkat çeken hususlardan bir diğeri de Emirî’nin kelimenin başında ve ortasında yazıldıkları yerlerde $b \hat{a}$ ve $y a ̂$ harflerinin imlâsında çok dikkatli davranmamış olmasıdır. Bu harfler söz konusu pozisyonlarda pek çok

$49 \mathrm{Bu}$ eser, bu makalenin yazarları ve Turgay Şafak tarafından yayına hazırlanmaktadır.

50 Emirî, Slfâtü'l-Âşılkin, 290".

51 age, $287^{\mathrm{b}}$. 
defa birbirleriyle karışacak şekilde imlâ edilmiştir. Emirî’nin çok iyi bir tahsil gördüğü, Arapça ve Farsçaya ileri derecede vâkıf olduğu ve hat konusunda iyi yetişmiş biri olduğu metinlerden çok vazıh bir surette anlaşılıyor olsa da imlâ ile ilgili zikredilmesi gereken bir başka husus ise Emirî’nin bazı kelimelerin imlâları konusunda dikkatsiz oluşudur. Kimi zaman aynı kelimelerin imlâsında tutarsız olduğu gibi, pek çok müstensih/kâtip tarafından özellikle bazı kelimelerde karıştırılması muhtemel olan $h a \hat{~ v e ~} h \iota$ harflerinde Emirî’nin de dikkatsiz davrandığı görülmektedir.

\section{Sonuç}

Emirî mahlasıyla şiirler yazan Mehmed bin Musa Paşa'nın en dikkat çeken yönlerinden biri kuşkusuz Anadolu sahasında 16. asırda Farsça şiir yazma geleneğini sürdürmüş olmasıdır. Öne çıkan bir diğer hususiyeti ise bugün elde olan bütün eserlerinde Farsça ve Türkçeyi beraber kullanmış olmasıdır. Elde bulunan iki divanında ağırlık Farsçada olmak üzere Türkçe şiirler de yer almıştır. Bu yazıda tanıtılan Uppsala yazmasında yer alan üç ayrı tercüme eserde de ağırlıkları farklı olmakla birlikte Türkçe ve Farsça karışık olarak kullanılmıştır. Bu tercümelerin kitaptaki sıraya göre ikincisi olan Ahlâk-ı Kâmilîn'de ise Farsçanın oranı diğer iki metne göre daha fazladır.

Burada tanıtılan yazmada yer alan her üç tercümede de metinler Emirî tarafından genişletilmiştir. Ayrıca Emirî Slfâtü'l-Âşıkîn'in mukaddimesinde metni tazmin ettiğini söylemektedir. Emirî, tavır olarak her bölümün sonundaki beyitleri Farsça nazmetmeye azami derecede özen göstermiş ve birkaç istisna hariç bu tavrına büyük ölçüde sadık kalmıştır.

$\mathrm{Bu}$ yazmanın ortaya çıkarılmasıyla daha önce Türkçeye tercüme edilmiş metinlerine rastlanmamış olan Kemâlnâme ile Sıfâtü'l-Âşıkîn adlı tasavvufi mesnevilerin 16. asırda Türkçeye tercüme edilmiş oldukları anlaşılmıştır. Bu yazı ile ayrıca Bostân'ın literatüre eklenen yeni bir tercümesi de saha çalışanlarının ilgisine sunulmuş olmaktadır.

Her ne kadar Emirî’nin iki divanında da Türkçe yazdığı gazeller arasında âşıkâne olanlar çoğunlukta olsa da tercüme ettiği eserlerin hepsi tasavvufi metinlerdir. Gerek şiirlerinden gerek bu metinlerde kullandığı kelime ve terimlerden 
hareketle Emirî’nin tasavvuf sahasını çok iyi bildiğini ve sâlikin vâkıf olduğu hallerin en azından kâhir ekseriyetine vukufunun bulunduğunu söylemek mümkündür. Hayatının son demlerinde kaleme aldığı anlaşılan eldeki eserlerinin tamamının, Emirî’nin dünya görüşü ve inanç dünyası ile aktardığı tecrübeler ve tavsiyeleri bakımından ayrıca incelenmeye ve değerlendirmeye layık eserler olduğunu söyleyebiliriz.

Eserlerinde zaman zaman Arapça mısralara da yer veren Emirî elsine-i selâse kültürü içinde yetişmiştir. Anadili olan Türkçede gayet selis şiirler söyleyebildiği gibi Arapça şiir nazmedebilmekte ve özellikle Farsça şiir söyleme konusunda iddialı görünmektedir. Her ne kadar emirlik yaptığını biliyor olsak da eserlerinden, dünyaya bakışından, dillere ve şiire olan vukufundan ve hattının sağlam yapısından hareketle Emirî’nin ilmiye sınıfına mensup olduğunu düşünmek mümkün görünmektedir.

Hem anne tarafından hem baba tarafından pek çok âlim, şair ve devlet adamı yetiştiren ailelere mensup olan Emirî’nin eserlerinde yer alan takrizlere de bakıldığında ilim ve sanat çevrelerine yakın olduğu ortadadır. Ancak buna rağmen gölgede kalmış olması, ismine şu ana kadar hiçbir biyografi eserinde rastlanmamış olması, üzerinde ayrıca durulması gereken bir husustur. Farsça şiirlerinde özellikle Anadolu sahasında müessir olmuş Farsça söyleyen şairleri anmış olmas1na rağmen Türkçe şiirlerinde Türkçe söyleyen hiçbir şairin ismini zikretmemiştir.

Emirî ayrıca 70 yaşlarında iken emirlik görevi ifa etmesiyle de Osmanlı Devleti bürokrasi tarihi açısından kayda değer bir örnek teşkil etmektedir. Emirî sayesinde biz Osmanlılarda 70 yaşına kadar emirlik yapılabildiğini görmüş oluyoruz. 


\section{Kaynakça}

Çiftçi, Mehdin. "Hankâh-Vefâ İlişkisi Bağlamında İstanbul'daki Üç Medrese: Ka'riye, Hâkâniye-i Vefầ ve Vefâ Medreseleri," Uludağ Üniversitesi Illahiyat Fakültesi Dergisi 25/1 (2016): 1-49.

Emirî. Ahlâk-ı Kâmilîn, yazma eser, Uppsala Üniversitesi Kütüphanesi, nr. O Vet. 63. . Bostân, yazma eser, Uppsala Üniversitesi Kütüphanesi, nr. O Vet. 63.

. Dîvân, yazma eser, İstanbul Üniversitesi Nadir Eserler Kütüphanesi, Farsça Yazmalar nr. 1222.

. Dîvân, yazma eser, Millî Kütüphane, nr. Yz A 85.

. Dîvân, yazma eser, Millî Kütüphane, nr. Yz A 85 .

. Dîvân-ı Râbi', yazma eser, Süleymaniye Yazma Eser Kütüphanesi, Fatih Koleksiyonu, nr. 3780.

. Dîvân-ı Sânî, yazma eser, Süleymaniye Yazma Eser Kütüphanesi, Fatih Koleksiyonu, nr. 3780.

. Sifâtü'l-Âşılkîn, yazma eser, Uppsala Üniversitesi Kütüphanesi, nr. O Vet. 63.

İzgi, Cevat. "Mehmed Sû̂dî Efendi," Türkiye Diyanet Vakfi İslâm Ansiklopedisi, c. 28, Ankara: Türkiye Diyanet Vakfi, 2003, s. 526-527.

Koç Konuksever, Serpil. “Emîrî Divanı: Metin İnceleme,” Yüksek Lisans Tezi, İstanbul Üniversitesi, Sosyal Bilimler Enstitüsü, 2012.

Tornberg, Carl Johan. Codices Arabici, Persici et Turcici Bibliothecae Regiae Universitatis Upsaliensis, Uppsala, 1849, s. 98-99.

Yaylal1, Yasemin. "Emîrî Divan1," Doktora Tezi, Atatürk Üniversitesi, Sosyal Bilimler Enstitüsü, 2013.

“Emîr̂̂’nin İkinci Divânındaki Farsça Şiirlerinde Geçen Ayetler,” İLTED 2/46 (2016): 247-267.

. "Emîrî Divan'ında Geçen Şahsiyetler," Atatürk Üniversitesi Türkiyat Araştırmaları Enstitüsü Dergisi 63 (2018): 117-134. 


\section{Ekler}

$$
\text { is }
$$

Emirî'nin Bostân tercümesi için söylediği Farsça iki beyit, Uppsala Yazması, 1 a

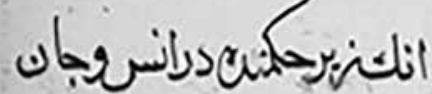

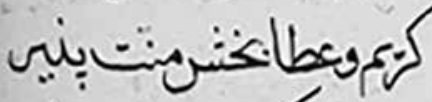

خ خ خ

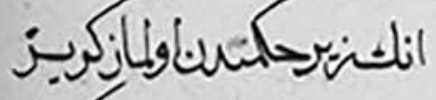

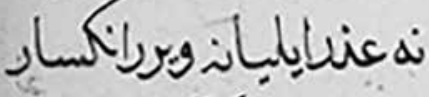
cicis

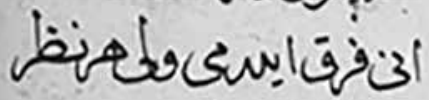
كا.

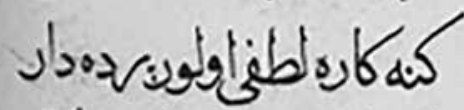

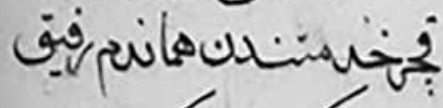

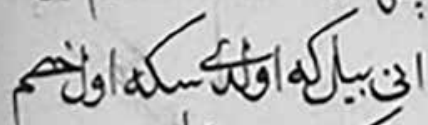

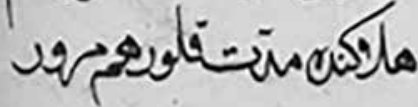

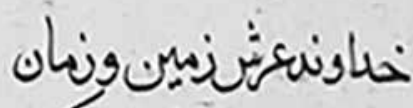
is

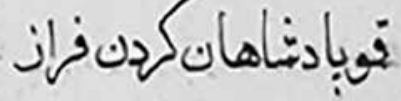
ن

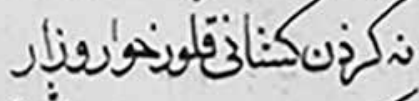

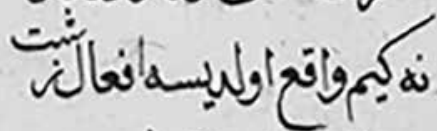

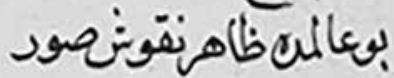

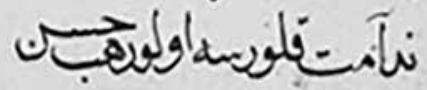

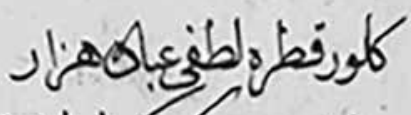

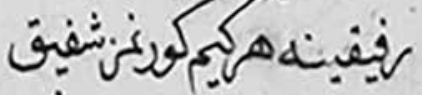
مثن?

Bostân tercümesinin başı, Uppsala Yazmasl, $1 b$ 
q.

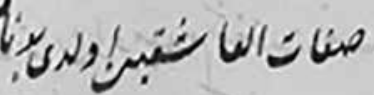

6.

ملإ

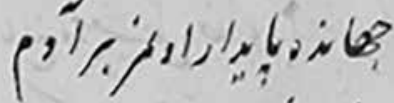

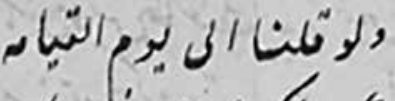

.

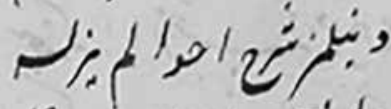

ب.

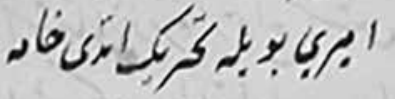

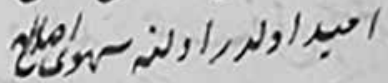
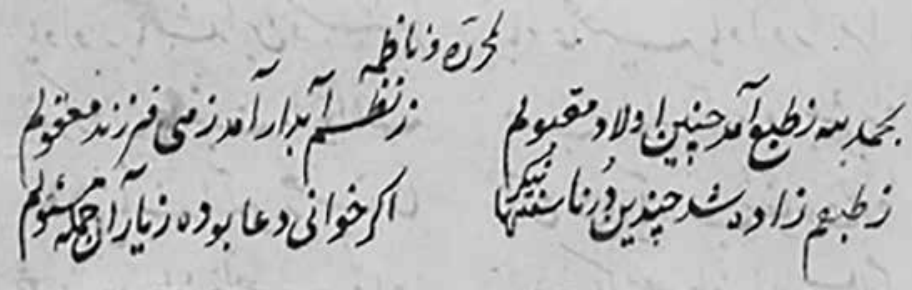

Sıfâtü'l-Âşıkîn tercümesinin sonu, Uppsala Yazması, 290b 